\title{
NARRATIVE- AND SPACE-MAKING IN THE CITY ON THE EXAMPLE OF LUBLIN
}

Keywords: memory, urban space, Holocaust, Jewish mysticism, Polish-Jewish history

Słowa kluczowe: pamięć, przestrzeń miejska, Holocaust, mistycyzm żydowski, historia polsko-żydowska

\section{Su m m a ry}

This paper discusses the literary, artistic, scientific, and educational narratives that are (re)created to facilitate the city's recovery of memory in the wake of the Holocaust. This is the case with Lublin. The story of the complete destruction of its Jewish quarter in the Second World War is a tragically familiar one in Central Europe, even though it had been silenced and forgotten for decades during the communist period. I would like to analyze an essayistic project that searches for a new language about a place left empty. How could one fill the void by making it mean something to new people, becoming their own narrative, and preserving the presence of the city's former inhabitants? How is it possible to create a new mythology of a place? I assume that such questions must have been the starting point for essays on Lublin by Władysław Panas (1947-2005), related to the commemoration in the context of urban space. My text comes in four parts. I begin with general information and historical background, as well as an introduction to the analysis of Panas's essay Oko Cadyka (The Eye of the Tzaddik) - the main subject of my paper - which exemplifies the reflection on the creation of narrative and urban space in contemporary humanities. In the second part, I focus on and contextualize the relationship between text and city that the essay postulates. The third part deals with theoretical approaches to interpretation. The fourth part underlines the scientific and critical aspects of Panas's text, which questions the language of science - the humanities, historiography, and theory in general. I end with a look at some artistic projects inspired by his images.

\section{STWORZYĆ MIASTO I JEGO PRZESTRZENIE W OPOWIADANIU - PRZYPADEK LUBLINA}

Streszczenie

Artykuł dotyczy opowieści - literackich, artystycznych, naukowych i edukacyjnych - które tworzone/odtwarzane są z myślą o przywróceniu pamięci miastu - Lublinowi - dotkniętemu tragedią Zagłady. Wydarzenie to objęte zostało amnezją narastającą przez dziesiątki lat w czasach 
komunizmu. Historia lubelskiej dzielnicy żydowskiej, doszczętnie zniszczonej podczas II wojny światowej, jest znamienna dla całego regionu Europy Środkowowschodniej. Głównym przedmiotem moich badań jest esej semiotyka i teoretyka literatury, Władysława Panasa (1947-2005), pt. Oko Cadyka, który - jak zakładam - powstał z intencją znalezienia odpowiedzi na fundamentalne ze społecznego i moralnego punktu widzenia pytanie: Jak zapełnić pustkę - wprowadzić w nią na nowo ludzi, dla których będzie ona coś znaczyć, a jej dawni mieszkańcy przestaną być dla nich obcy? Jak stworzyć nową mitologię miejsca? Artykuł składa się z czterech części. Rozpoczynam od informacji ogólnych i tła historycznego. W części drugiej skupiam się na (re)konstruowanych w Oku Cadyka relacjach między tekstem - zarówno samego eseju, jak i napisu na macewie z grobu Cadyka (Jakuba Izaaka Horowica) - a miastem. Część trzecia prezentuje ramy teoretyczne służące do jego interpretacji. W części czwartej wskazuję na obecne w analizowanym eseju jawne i ukryte odniesienia do współczesnej humanistyki - filozofii, teorii literatury i historiografii. Na zakończenie opisuję współczesne projekty artystyczne, realizowane w Lublinie i inspirowane imaginarium wykreowanym przez Panasa.

\section{Panas's Metaphysical Tourism}

When situating Lublin in its cultural-historical context, we must recognize that we enter a territory that cannot be mapped in terms of nation states. In this region, the cultural space was historically multi-ethnic and multicultural, strongly influenced by the Jewish population. For example, the founder of Polish-Jewish historiography, Majer Bałaban, writes about the history of Jews in Lublin in his monograph Die Judenstadt von Lublin, published in Berlin in 1919. ${ }^{1}$ Adina Cimet, a contemporary historian, also focuses on the Jewish Lublin and uses the term "parapolis" to describe the parallel life in the Christian and Jewish parts of the city, both divided and connected by the Grodzka Gate.

The located here "Grodzka Gate - NN Theatre" Centre is a cultural institution founded in 1990 whose activities, art, and educational programs deal with issues of cultural heritage and the Polish-Jewish past of Lublin, silenced during communism. Since its beginnings, the founder Tomasz Pietrasiewicz cooperated with Władysław Panas, a literary scholar and author of books about Polish poetry and modernist prose. Step by step, together they replace the former poor semantics of the city with a new narrative that retells its complex history.

Panas's writings played an important role in the process. In the 1990s, he wrote a cycle of essays about the city, guiding the readers through its multicultural heritage, in which Panas treats Lublin as a palimpsest, scraping off its existing semantic surfaces to find beneath them the messages and texts encompassed by

1 "Grodzka Gate - NN Theatre" Center published a 2012 reprint of the German edition of the 1919 book with a Polish translation. Majer Bałaban, Die Judenstadt von Lublin (Lublin: Ośrodek "Brama Grodzka - Teatr NN," 2012).

${ }^{2}$ Adina Cimet, Jewish Lublin: A Cultural Monograph (Lublin: "Grodzka Gate - NN Theater" Center, Maria Curie-Skłodowska University Press, 2009), 28-31. 
the collective unconscious. ${ }^{3}$ He describes his work on Lublin cultural storehouses of memory as the "promotion of 'metaphysical tourism,' that is a form of tourism which has time, does not hurry, has an infinite amount of time and infinite patience." ${ }^{4}$

I will focus on one of Panas's essays Oko Cadyka (The Eye of the Tzaddik) - written in 1994, published in 1999, translated into English by Marcin Garbowski in 2015 - in which he tries to read the city as a symbolic space. The text reveals the process of creating a myth, a mythology of a place that goes through some well-known historical events, which belong to mainstream knowledge and are represented through memorials in public space. For example, the Union of Lublin in 1569 that resulted in the creation of the Polish-Lithuanian Commonwealth. Instead of repeating familiar historical patterns, Panas selects an unknown figure to patiently and thoroughly develop a story of Hasidim Jacob Isaac Horowitz called the Seer of Lublin (1745-1815) who made the city an important place on the map of the Hasidic movement. There is a lot of hagiographic literature in Yiddish about tzaddik Horowitz, tales and legends about miracles he performed. ${ }^{5}$ According to these historical sources, he lived near the Grodzka Gate, had a circle of followers, wanted to speed up the arrival of the Messiah, and died in mysterious circumstances. Some traces of his life and work appear in literature, for example in Martin Buber's Gog and Magog ${ }^{6}$ or Jiří Langer's The Nine Gates to the Chassidic Mysteries. ${ }^{7}$

Panas's essay starts with a remarkable poem by Zbigniew Herbert, Studium przedmiotu (Study of the Object): "mark the place / with a black square / where the object stood/ which is not here / this will be / a simple lament / about the beautiful absence." ${ }^{8}$ The quoted stanza contains all keywords necessary to understand the text and announces further considerations, which can be read as a Kaddish for the vanished Jewish district. Panas looks for the place where the house of tzaddik Horowitz could have stood, which for his believers was the center of the world, the "Axis Mundi." Panas tries to reconstruct it according to symbolic traces found in cultural texts: maps, poems, and artifacts such as a matzevah.

${ }^{3}$ Panas's collected essays on Lublin have been published as Magiczne miasto: szkice i fragmenty lubelskie (Lublin: Ośrodek "Brama Grodzka - Teatr NN," 2017).

${ }^{4}$ Władysław Panas, "Magiczne miasto," Scriptores, no. 33 (2008): 170.

${ }^{5}$ The collection of hagiographic texts about the Seer of Lublin was translated into Polish and published as Księga cudów Widzacego, eds. Jan Doktór, Agnieszka Żółkiewska, Nirit Neeman, trans. Agnieszka Żółkiewska (Lublin: Ośrodek "Brama Grodzka - Teatr NN," 2015).

${ }^{6}$ Martin Buber, Gog and Magog: A Novel, trans. Ludwig Lewisohn (Syracuse, NY: Syracuse University Press, 1999), 103-109.

${ }^{7}$ Jiří Langer, Nine gates to the Chassidic Mysteries, trans. Stephen Jolly (New York: Behrman House, 1976), 179-198.

${ }^{8}$ Władysław Panas, Oko Cadyka / The Eye of the Tzaddik, trans. Marcin Garbowski (Lublin: Warsztaty Kultury w Lublinie, 2015), 63. 


\section{Between Literature and Theory}

While rooted in local history and heritage, we may also read Panas's multi-layered essay as a text neither about the tzaddik nor about Lublin. This sentence may appear paradoxical, but it points to the fact that Oko Cadyka does not deal with Horowitz as a historical figure or with his place of residence. The essay plays with history and geography as if they were only literary constructs. They are projected onto each other in order to create new meanings or - to quote another exegete of the province, Bruno Schulz - "short circuits of sense." The tzaddik has only an exemplary function in the essay, providing an impulse to introduce much broader topics. Panas places in the center of his interest the text itself.

Panas's essay consists of ten parts named after the letters of the Hebrew alphabet, from Aleph to Jod, but the allusions to Jewish mysticism are not the only field of reference for Panas. He is not a Judaist who would analyze Kabbalistic primary literature and study the writings by the foremost rabbi and Jewish mystic Isaac Luria in the original. Instead, Panas refers to secondary sources, among others the works by Gershom Scholem. However, this does not play a significant role in Panas's argument, because he sees himself primarily as a literary scholar and theorist interested in the broadly understood cultural semiotics. In his essay, Panas draws a much broader perspective beyond the local connotations and raises questions now intensively explored by the humanities: How to define memory? What makes a (scholarly/theoretical/scientific) text? What does a city analysis or historiography mean?

What sheds new light on Panas's text and explains the diversity of discourses, theories, and disciplines that he combines is the context of urban and memory studies, as well as the theory and criticism of humanities in the sense of the German term Wissenschaftstheorie und -kritik. The following considerations do not intend to depict these fields fully and exhaustively, but they merely try to open up a web of possible associations evoked in the essay. Panas uses categories from various research fields like semiotics, hermeneutics, geopoetics, philosophy of history, or phenomenology. Throughout Panas's essay, there appear implicit and explicit references to the writings by Martin Buber, Mircea Eliade, Carl Gustav Jung, Maurice Halbwachs, Emmanuel Levinas, Yuri Lotman, Maurice Merleau-Ponty, Pierre Nora, and Gershom Scholem. Panas reflects on his own methodology in the text, directly commenting on his approach and exposing his methods and strategies: "There is such a discipline - geo-poetics. I am trying to apply it here. Obviously in combination with all the rules of Kabbalistic

\footnotetext{
${ }^{9}$ Bruno Schulz, The Collected Works of Bruno Schulz, ed. Jerzy Ficowski, trans. Celina Wieniewska, Walter Arndt and Victoria Nelson (London: Picador, 1998), 372.
} 
hermeneutics." ${ }^{10}$ Although Panas uses technical terms, incorporates methodological meta-commentaries, and moves within the framework of scientific argumentation, his essay can also be read as a work of literature.

Oko Cadyka teems with intertextual allusions. Not only philosophy but also literature plays an important role in Panas's narrative. He mentions by name and quotes poets like Józef Czechowicz and broaches various literary references. The search for Axis Mundi in combination with the Hebrew alphabet resembles the short story The Aleph (1945) by Jorge Luis Borges. There, the Aleph stands for a special point in space from which one can see the unimaginable universe: "[the Aleph is] the only place on earth where all places are - seen from every angle, each standing clear, without confusion or blending." ${ }^{11}$ Borges's protagonist finds this point in a very unspectacular location: in the basement of a house where his friend secretly hides it from the world until the building is demolished. Panas also seems to seek something similar like the Aleph, a trace that could indicate the place of residence of tzaddik Horowitz.

The mention of Borges helps to underline the literary dimensions in Panas's text. In another short story, Tlön, Uqbar, Orbis Tertius (1940), Borges again problematizes an impossible spatial phenomenon or - as Carlos Fuentes notices - space is the main protagonist of his narrative. ${ }^{12}$ "Uqbar" is the name of a country that appears as a keyword only in one edition of the Anglo-American Encyclopaedia. Apart from this instant, nobody heard about it. The first-person narrator speculates that the encyclopedia article may be a part of an intrigue of intellectuals who came up with an idea of an imaginary world called "Tlön" that has its own language, logic, and even laws of physics. To his astonishment, however, he begins to discover elements of Tlön in his surroundings, objects that he had known until then only from the writings by this suspicious group of scholars. These things transform and "contaminate" his reality, become a part of it, and - to use the quote by another Borges interpreter, John Barth - they "imagine themselves into existence."13 The boundaries between reality and fiction become fluid, thus increasing the feeling of insecurity.

${ }^{10}$ Władysław Panas, op. cit., 85.

${ }^{11}$ Jorge Luis Borges, Aleph and other stories, 1933-1969, Together with Commentaries and an Autobiographical Essay, trans. Norman Thomas di Giovanni (New York: E. P. Dutton, 1970), 23.

12 "In Borges's stories time and space become characters, with the same titular eminence as Tom Jones or Anna Karenina in realist literature.... In The Aleph, and Tlön, Uqbar, Orbis Tertius, space is the protagonist, with as many virtues as the hero or heroine of a realist novel." Carlos Fuentes, The Great Latin American Novel, trans. Brendan Riley (Victoria, TX: Dalkey Archive Press, 2016), 130-132.

${ }^{13}$ John Barth, "The Literature of Exhaustion," in The Friday Book: Essays and Other Non-Fiction (Baltimore: Johns Hopkins University Press, 1984), 71. 
A similar idea of interaction between the textual and the "real" world characterizes Panas's essay. Urban space does not function here as neutral, ready, or given. It is the text that starts to model urban space and create its perceptual framework. Panas determines the conditions for our perception of space, directs our view, and fixes our gaze on his projections so that they merge with descriptions of Lublin. For example, he lists the conditions which frame our perception: "First, if we find ourselves on the proper level and, second, if we find ourselves at the right distance and, third, if we gaze at it from the proper angle."14

This strategy is especially evident in the parts of the text about the matzevah, which in the essay does not simply have the function of a tombstone marking a grave. The matzevah not only reminds us of tzaddik Horowitz, but also becomes a signpost and gains new meaning related to the topography of the city. Instead of just marking the absence, the matzevah refers to something material, to the here and now. Something virtual participates in the reality and turns into its element. Panas even compares the matzevah with the city map and argues that both should be thought of together:

The city maps and the matzevah verify and interpret each other. Their qualities complement and transcend each other. A simple city map, a topographic sketch, a very prosaic thing, begins to attain a symbolic meaning. A completely poetic, surreal and symbolic matzevah acquires the value of a precise plan. ${ }^{15}$

The matzevah acquires new qualities, can model the space, mirrors the topography of the city, and simultaneously is mirrored by the city that takes its shape. Both complement each other: "The castle and the castle square, that encompasses the space after the Seer, the ravages Place, reproduces the shape of the Tzaddik's matzevah. A gigantic tombstone cast into space.... An icon of matzevah."16

Moreover, the matzevah is special because it represents a miniature of itself: "matzevah within the matzevah." ${ }^{17}$ One can describe this phenomenon as a representation in a representation. Panas reads the matzevah as a self-referential (cultural) text that can be projected onto the space and is also able to shape and arrange it. The matzevah is seen as a second-degree image that interacts with the reality and transforms it. It is no longer an object of description but a form in the process of eternal becoming. Or, to quote Panas, it is "the tension of accumulated energy, a concentration of power. A form of contained, immobilized dynamics." 18

\footnotetext{
${ }^{14}$ Władysław Panas, op. cit., 81.

${ }^{15}$ Ibidem, 85.

${ }^{16}$ Ibidem, 82.

${ }^{17}$ Ibidem, 81 .

${ }^{18}$ Ibidem, 87.
} 
In other words, the matzevah becomes the city and the city - the matzevah. Panas's essay demonstrates this transformation or is like a performance, in which text and space come together, redefine each other, and merge to form the image of the eye. The urban space receives a completely new quality. The castle square which the viewer perceives as empty on the primary level of perception transforms into the attribute of the Seer of Lublin, fills with the possibilities of cognition and memory. The viewer can "activate" these energies by becoming a reader and learning from the essay how to see. After reading, one can recognize the eye of the tzaddik in the empty square. The city "looks at us," and that look of space requires a response. Hence, we as readers enter the sphere of memory in the role of knowing observers and become actors in the dialogical process of memory.

\section{Approaches and Theoretical Contexts}

Panas's interpretation of the matzevah has prosaic traits and creates a thoroughly typical Borgesian constellation that leads to a situation of undecidability and the intermingling of textual and extra-textual reality. It also includes theoretical reflection on the relationship between the city and the text. There are several theoretical approaches that can be used to describe what happens in Oko Cadyka. The writings of the Russian semiotician Lotman offer the language to point out the tendencies in the essay: Panas demonstrates how "the structure of the space of a text becomes a model of the structure of the space of the universe" and how "the elements within a text becomes the language of a spatial modeling." 19

Jean Baudrillard's terms "simulacrum" and "hyperreality" seem to fit well in this context. The two notions highlight the fact that Panas marks the urban space with texts, that is, he marks it with the matzevah. The matzevah serves as a landmark, turns into a reference point in the "real" world, and simultaneously is an object that refers to itself. ${ }^{20}$ Panas's Lublin is based on texts and perceived through their prism. His essay transforms referentiality into intertextuality while the lack of reference to an extra-linguistic reality means that there is no city outside the texts. For Panas, any reference to reality can be considered as obsolete because, from an etymological viewpoint, topography has a textual

${ }^{19}$ Yuri Lotman, The structure of the artistic text, trans. Ronald Vroon (Ann Arbor: University of Michigan Press, 1977), 217.

${ }^{20} \mathrm{Cf}$. Baudrillard's definition of a simulacrum that is "never exchanged for the real, but exchanged for itself, in an uninterrupted circuit without reference or circumference. Such is simulation, insofar as it is opposed to representation." Jean Baudrillard, Simulacra and simulation, trans. Sheila Faria Glaser (Ann Arbor: University of Michigan Press, 1994), 6. 
nature and contains the gesture of writing. The essay seems to postulate that everything is text and there is no place without writing. On the one hand, Oko Cadyka focuses on the parallelization of the city and the text, like in Michel Butor's essays. ${ }^{21}$ On the other hand, Panas shows the phenomenon of text's self-referentiality. The essay receives self-referential meaning and transforms itself into the main subject of its own reflection.

Both aspects enable an interpretation of the essay Oko Cadyka in the context of popular tendencies in the humanities at the time of its writing. For instance, we may link Panas's essay with the "spatial turn" that since the 1980s is described as the rediscovery of space in cultural history. In their analysis of the modernization processes, such authors as Henri Lefebvre, Michel Foucault, and Fredric Jameson critically examine the usual categories of spatial distribution like the center and the periphery or the countryside and the metropolis. The scholars employ these explorations to cognitively map and recognize culture through power relations, observing the world as the stage of conflicts and tensions, for instance, between something distinctive and universal or homogeneous and heterogeneous. Hence the scientific careers and attractiveness of such categories as the borderland as agonistic space and the battlefield between different systems of dependencies, or the liminality, hybridization, palimpsest, trace, and void. Hence, also, the renaissance of "little homelands," small narratives, micro-communal utopias, and the notion of memory, which foregrounds literature as the tool for shaping and retrieving the suppressed, region-based memory. Reading landscapes and spaces as cultural-historical palimpsests was the focus of the spatial turn. ${ }^{22}$

The interdisciplinary approach that Panas so consistently pursues was the method of choice at the time. What constructs the special poetics of Panas's text is the self-reflectivity and meta-commentaries, intertextuality and metafictionality, the interruption of the ordinary linearity of the text initiated with the division of the essay according to the Hebrew alphabet, the questioning of logical-rational "scientific" reasoning. A "postmodern reply" or revision of the past with irony - to put it in Umberto Eco's terms - could not be presented more evidently. ${ }^{23}$ But that is not to say that Oko Cadyka should be dismissed as postmodern.

${ }^{21}$ Cf. Michel Butor, "La ville comme texte," in Répertoire V (Paris: Éditions de Minuit, 1982), $33-42$.

${ }^{22}$ More about the spatial turn, vide Doris Bachmann-Medick, "Spatial Turn," in idem, Cultural Turns: New Orientations in the Study of Culture, trans. Adam Blauhut (Berlin/Boston: De Gruyter, 2016), 211-243.

${ }^{23}$ Cf. Umberto Eco, Postscript to "The Name of the Rose", trans. William Weaver (San Diego: Harcourt Brace Jovanovich, 1984), 47. 
In the essay, Panas exposes the diversity of discourses and their fusion, already visible in the structure of the text itself. The alphabet as something cyclical and repeatable, understood as an attribute of eternity, lends the text a ritual dimension and creates a bridge between the secular and the cosmic order, which includes another aspect of the theory of science. Thanks to the alphabetical division, the described phenomena are located outside of the time frame; they tend to something that can be defined as origins or primary sources of being. Categories such as aura, messianism, or ritual, which belong to the religious vocabulary, appear in a theoretical text and illustrate its hybrid character. Panas emphasizes how the scientific language, the language of theory, is embedded in various discourses - religious, literary, philosophical, public - and points out that there is no axiologically "neutral" way of reflection on historical facts. ${ }^{24}$ Therefore, Panas creates a complex narrative in which several languages from different registers flow together: poems, city maps, Hasidic stories, philosophical tracts, and inscriptions on the matzevah. Thus, the essay approximates the object of description by transforming it into the subject of discourses.

This approach is characteristic for deconstructivism. Panas seems to agree with Derrida that any language about a phenomenon "cannot be excluded from its object" 25 and that the culture/text analysis requires the use of "the parodying heterogeneity of the style, the styles." ${ }^{26}$ It is only thanks to this diversity that a text avoids the reduction of the described phenomenon to an object of unambiguous definitions, let the space free for the undecidability and further interpretations, as well as distance itself from the hermeneutic project "which postulates a true sense of the text." ${ }^{27}$ We may understand the radical anarchy and heterogeneity of Panas's text, according to his writing style and methodology, as an ironic play with conventions.

The irony of the text is also expressed in the playful handling or binding of common dichotomies such as the visible and the invisible or the transcendent and the immanent. Panas points out the tensions between these oppositions, but they do not function in the text as contradictions. Similarly to Merleau-Ponty's late work The Visible and the Invisible (1964), Panas tries to link together presence and absence, seeing and not-seeing, showing and hiding. ${ }^{28}$

${ }^{24}$ Vide Kerwin Lee Klein, “On the Emergency of Memory in Historical Discourse,” Representations, no. 69 (2000): 145.

${ }^{25}$ Jacques Derrida, "Of an Apocalyptic Tone Recently Adopted in Philosophy," trans. John P. Leavey, Jr., Semeia, no. 23 (1982): 90.

${ }^{26}$ Jacques Derrida, Spurs: Nietzsche's Styles, trans. Barbara Harlow (Chicago \& London: University of Chicago Press, 1979), 99.

${ }^{27}$ Ibidem, 107.

${ }^{28} \mathrm{Cf}$. Maurice Merleau-Ponty, The Visible and the Invisible. Followed by Working Notes, ed. Claude Lefort, trans. Alphonso Lingis (Evanston: Northwestern University Press, 1968), 130-155. 
On the one hand, he problematizes discourses that refer to invisible ideas like Jewish mysticism. On the other hand, his text attempts to be understood as an "exercise" to develop new kinds of seeing and interpreting the urban space. This suggestion of a new perspective at well-known things in the surroundings can be associated with ideas postulated in art of the 1920s, especially photography and the movement called Neues Sehen or New Vision, formed mainly by young Russian Constructivists like Alexander Rodchenko and Bauhaus teacher László Moholy-Nagy; or in the aesthetics and art theory like one of the most important voices of Russian Formalism, Viktor Shklovsky and his concept of "defamiliarization" that is "seeing the world with different eyes." ${ }^{29}$ Panas also suggest an alternative de-automated way of reading the urban space, in which the absent and invisible cultural-historical context comes to the fore.

\section{The Power of Storytelling}

The language in Panas's essay uses strong imagery, particularly the geometric figures projected onto the space like arches, circles, semicircles, triangles, or "tautened bowstring." ${ }^{30}$ Panas seems to underline that only imagination can construct and revive the forgotten history of Lublin. A simple list of historical events would not suffice. According to Panas, the discovery of "the historical truth" is a utopian concept, which ignores the observation that "the facts" exist or are conceptualized only in language. The facts cannot be discovered but only invented by a poetic language with the help of metaphors, narratives, rhetorical figures, and tropes, because talking about the past is neither neutral nor objective. In the end, the city in Panas's text does not transform into a mere augmented space, simply enlarged by a symbolic dimension; it is not a transparent medium of information about the past. Rather, Lublin becomes the imagined reality itself. There is no other reality except the "invented" historical narrative - invented by Panas. Therefore, just like Hayden White, Panas seeks to initiate "imaginative processes" of thinking in images and figurative associations that characterize historiography, literature, and mythical thought together. ${ }^{31}$

${ }^{29}$ Victor Shklovsky, "Ostranenie", in Viktor Shklovsky: A Reader, trans. Alexandra Berlina, (New York: Bloomsbury Publishing, 2017), 334. Vide Renate Lachmann, "Die Verfremdung und das neue Sehen bei Viktor Šklovskij," Poetica, no. 3 (1970): 226-249.

${ }^{30}$ Władysław Panas, op. cit., 87.

31 "By imaginative processes I mean those that feature the kind of thinking in images and figurative modes of association characteristic of poetic speech, literary writing, and, yes, mythical thought.” Hayden White, “An Old Question Raised Again: Is Historiography Art or Science? (Response to Iggers)," Rethinking History, no. 4:3 (2000): 398. 
The essay's awareness of the relativity and constructability of history and its negotiable character go hand in hand with the emphasis on the power of storytelling. That is why Panas mentions the Hasidic story that he quotes after Scholem ${ }^{32}$ who, in turn, tells it after Agnon. The tale is about a Hasidim worrying how to face difficult tasks if their Master is gone and they do not have access to some parts of the ritual:

"We can no longer light the fire, nor do we know the right prayer; we even don't know where the place in the forest is located, but we can always tell the story about how everything happened." And the tzaddik's tale was just as effective as the deeds of those who came before him. ${ }^{33}$

A quote in a quote, a story in a story that says: "when all is lost, the narrative about the absence can make wonders." Again, a self-referential moment in the essay emphasizes that a narrative always postulates participation and interaction. The essay is not a ready project, the narrative functions only by re-telling.

The act of storytelling is crucial in Oko Cadyka as it constructs the city. Storytelling can mark the urban space and fill it with meanings. Panas shifts absence and emptiness that characterize Lublin to the center of his interests and of the city map; a non-typical situation for Western European cities. ${ }^{34}$ However, Panas's essay does not only claim to commemorate the destroyed world but tries to recreate it, to bring it back to memory, the public sphere and awareness. With the Castle Square, which merges into the eye of the tzaddik, Panas seems to create a new place of remembrance or, to use Jan Assmann's terms referring to writings by Aby Warburg, a commemorative figure that can form "'islands of time,' islands of a completely different temporality suspended from time," which has a special "mnemonic energy" and can influence collective consciousness and cultural memory. ${ }^{35}$ Panas's essay

\footnotetext{
${ }^{32}$ Gershom Scholem, Die jüdische Mystik in ihren Hauptströmungen (Frankfurt am Main: Suhrkamp, 1993), 384.

${ }^{33}$ Władysław Panas, op. cit., 70.

${ }^{34}$ For Barthes, an empty city center would be a paradox because all cities in Western tradition are to be loaded with many meanings: "[All cities in the West] are concentric; but also, in accord with the very movement of Western metaphysics, for which every center is the site of truth, the center of our cities is always full: a marked site, it is here that the values of civilization are gathered and condensed: spirituality (churches), power (offices), money (banks), merchandise (department stores), language (agoras: cafes and promenades): to go downtown or to the center-city is to encounter the social 'truth,' to participate in the proud plenitude of 'reality'." Roland Barthes, Empire of Signs, trans. Richard Howard (New York: Hill and Wang, 1992), 30.

${ }^{35}$ Jan Assmann, “Collective Memory and Cultural Identity," trans. John Czaplicka, New German Critique, no. 65 (1995): 129.
} 
demonstrates the process of how to apply new meanings and reflects beyond that: on the meta-level about the limits of the text, about the possibilities of its effectiveness, about its performative power. Panas proposes a different view on the theory, which can be understood as a challenge to reality, participation, taking action, and intervening in the world inseparably connected with it or constituting its symbolic universes, as well as a performative answer to it; to them. This means a different acting attitude, located somewhere between theory and practice, underlying the immersion of the writer and researcher in the world or topic of research, and the readiness on both sides to transform each other and question oppositions such as city, text, subject, object. The acting object, the object that is to be performed and not intellectually grasped or simply understood, is copied, repeated, and thus transformed; just like the constituting self. Therefore, we may consider Panas's essay in the context of the "performative turn" in the humanities and social sciences of the 1990s, and interpret it as a cultural performance. Panas does not prove a theory, he does not realize any predetermined, transcendental intention, but he generates the subject of his reflections in the act of writing and tries to initiate through it a cultural change. At the end of Panas's text, the Castle Square in the form of the eye of the tzaddik seems to look at the reader - and invites us to enter into dialogue with this space.

The essay by itself also undertakes a dialogue with the surroundings and the city; - it has begun shaping the collective experience of Lublin inhabitants and, thus, has become a reference framework for them. Lastly, we must refer to examples of interaction between Panas's text and the cultural remembrance practices in Lublin. Noteworthy, the light installation "Oko Cadyka" by the visual artist Jarosław Koziara during the festival "Open City" in 2010 formed a huge circle of light in the middle of the castle square in Lublin. Furthermore, the City Council accepted the 2015 version of the official logo of the city of Lublin, which plays with the motif of the eye. Moreover, the Hebrew alphabet that is significant for Panas's text is used in the art installation "Nie/Pamięć Miejsca" (Mis/Remembrance of the Place), ${ }^{36}$ opened in 2017 by the "Grodzka Gate - NN Theatre" Center at the former Umschlagplatz. From that place, Germans deported 28,000 Jewish inhabitants of Lublin to the death camp in Bełżec during the Second World War. The installation is a dark metal container, which can be entered from the street side, perforated by openings in the form of Hebrew letters that allow the light to shine through.

\footnotetext{
${ }^{36}$ More about the art installation, vide Tomasz Pietrasiewicz, Theatre of Memory by the NN Theatre: 1997-2017, trans. Monika Metlerska-Colerick (Lublin: "Grodzka Gate - NN Theater" Center, 2017), 277-291.
} 


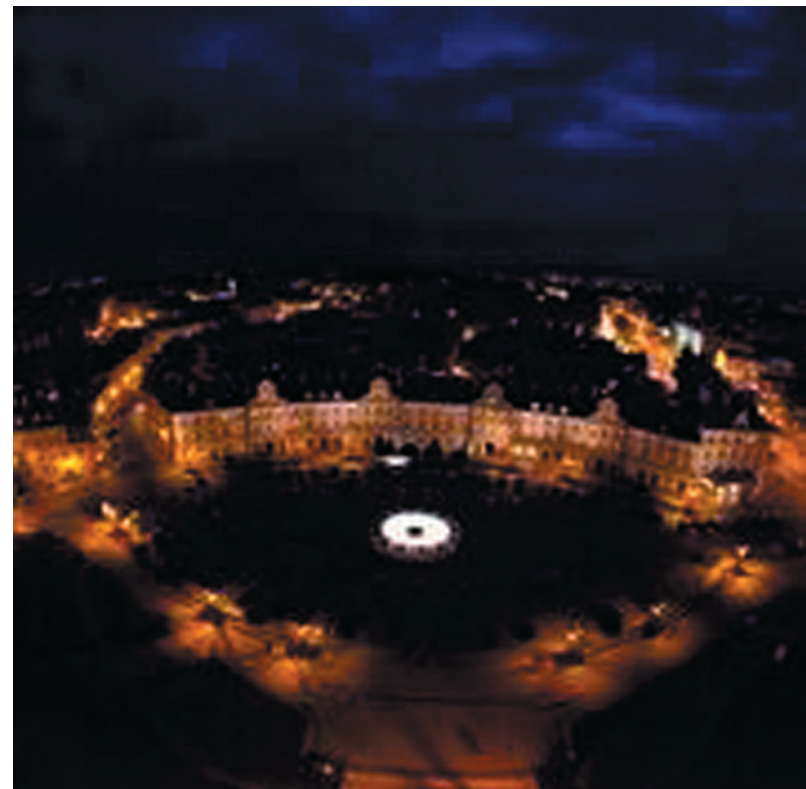

The light installation "The Eye of the Tzaddik" ("Oko Cadyka") by the visual artist Jarosław Koziara during the festival "Open City" in 2010. Photographed by Wojtek Kornet WiP-Studio Lublin.

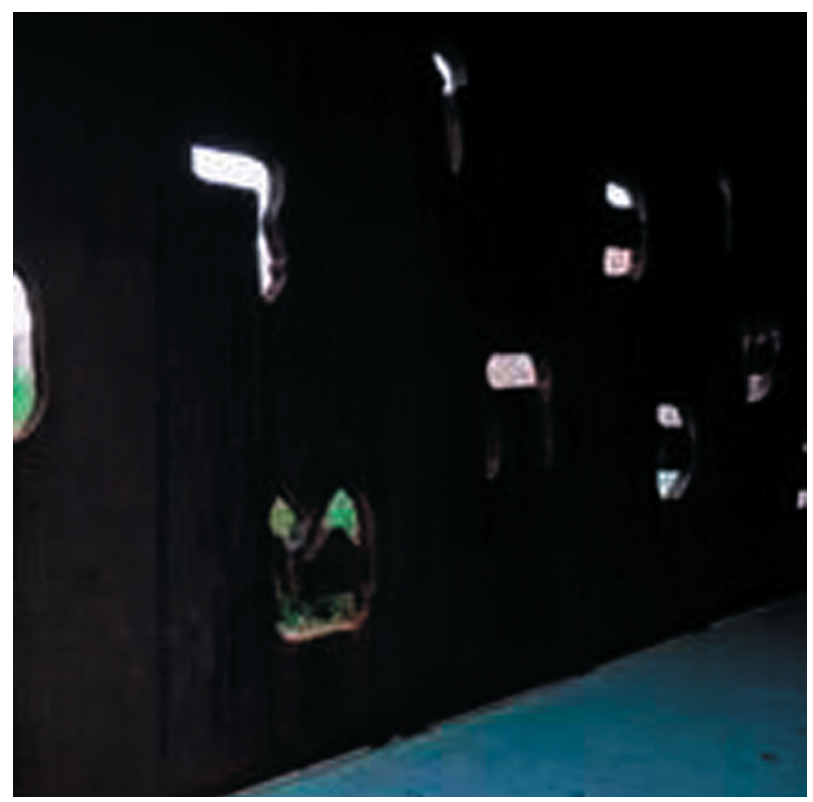

The art installation "Mis/Remembrance of the Place" ("Nie/Pamięć Miejsca"). Photographed by Agnieszka Hudzik. 


\section{References}

Assmann, Jan. "Collective Memory and Cultural Identity," trans. John Czaplicka. New German Critique, no. 65 (1995): 125-133.

Bachmann-Medick, Doris. "Spatial Turn." In idem, Cultural Turns: New Orientations in the Study of Culture, trans. Adam Blauhut. Berlin/Boston: De Gruyter, 2016, 211-243.

Bałaban, Majer. Die Judenstadt von Lublin. Lublin: Ośrodek "Brama Grodzka - Teatr NN," 2012.

Barth, John. "The Literature of Exhaustion." In The Friday Book: Essays and Other Non-Fiction. London: The John Hopkins University Press, 1984, 62-76.

Barthes, Roland. Empire of Signs, trans. Richard Howard. New York: Hill and Wang, 1992.

Baudrillard, Jean. Simulacra and Simulation, trans. Sheila Faria Glaser, Ann Arbor: University of Michigan Press, 1994.

Borges, Jorge Luis. Aleph and Other Stories, 1933-1969, Together with Commentaries and an Autobiographical Essay, trans. Norman Thomas di Giovanni. New York: E. P. Dutton, 1970.

Buber, Martin. Gog and Magog: A Novel, trans. Ludwig Lewisohn. Syracuse, NY: Syracuse University Press, 1999.

Butor, Michel. "La ville comme texte.” In Répertoire V. Paris: Éditions de Minuit, 1982, $33-42$.

Cimet, Adina. Jewish Lublin: A Cultural Monograph. Lublin: "Grodzka Gate - NN Theater" Center, Maria Curie-Skłodowska University Press, 2009.

Derrida, Jacques. Spurs: Nietzsche's Styles, trans. Barbara Harlow. Chicago \& London: University of Chicago Press, 1979.

Derrida, Jacques. "Of an Apocalyptic Tone Recently Adopted in Philosophy,” trans. John P. Leavey, Jr. Semeia, no. 23 (1982): 63-97.

Doktór, Jan, et Agnieszka Żółkiewska, Nirit Neeman, eds. Księga cudów Widzacego, trans. Agnieszka Żółkiewska. Lublin: Ośrodek "Brama Grodzka - Teatr NN," 2015.

Eco, Umberto. Postscript to "The Name of the Rose", trans. William Weaver. San Diego: Harcourt Brace Jovanovich, 1984.

Fuentes, Carlos. The Great Latin American Novel, trans. Brendan Riley. Victoria, TX: Dalkey Archive Press, 2016.

Klein, Kerwin Lee. "On the Emergency of Memory in Historical Discourse." Representations, no. 69 (2000): 127-150.

Lachmann, Renate. "Die Verfremdung und das neue Sehen bei Viktor Šklovskij." Poetica, no. 3 (1970): 226-249.

Langer, Jiří Mordechai. Nine gates to the Chassidic Mysteries, trans. Stephen Jolly. New York: Behrman House, 1976.

Lotman, Yuri. The Structure of the Artistic Text, trans. Ronald Vroon. Ann Arbor: University of Michigan Press, 1977.

Merleau-Ponty, Maurice. The Visible and the Invisible. Followed by Working Notes, ed. Claude Lefort, trans. Alphonso Lingis. Evanston: Northwestern University Press, 1968. 
Panas, Władysław. "Magiczne miasto.” Scriptores, no. 33 (2008): 160-176.

Panas, Władysław. Oko Cadyka / The Eye of the Tzaddik, trans. Marcin Garbowski. Lublin: Warsztaty Kultury w Lublinie, 2015.

Panas, Władysław. Magiczne miasto: szkice i fragmenty lubelskie. Lublin: Ośrodek "Brama Grodzka - Teatr NN,” 2017.

Pietrasiewicz, Tomasz. Theatre of Memory by the NN Theatre: 1997-2017, trans. Monika Metlerska-Colerick. Lublin: “Grodzka Gate - NN Theater" Center, 2017.

Scholem, Gershom. Die jüdische Mystik in ihren Hauptströmungen. Frankfurt am Main: Suhrkamp, 1993.

Schulz, Bruno. The Collected Works of Bruno Schulz, ed. Jerzy Ficowski, trans. Celina Wieniewska, Walter Arndt and Victoria Nelson. London: Picador, 1998.

Shklovsky, Viktor. “Ostranenie.” In Viktor Shklovsky: A Reader, trans. Alexandra Berlina. New York: Bloomsbury Publishing, 2017, 334-342.

White, Hayden. "An Old Question Raised Again: Is Historiography Art or Science? (Response to Iggers)." Rethinking History, no. 4:3 (2000): 391-406. 